\title{
FARMING EXPERIENCES IN THE CENTRAL PUMICE COUNTRY
}

\section{J. N. WARD \\ "G reenvale", Whakumaru}

\author{
SETTLEMENT
}

IN December 1959, fifteen farms were ballotted for in the Rotorua area and the writer was lucky enough to draw one at Whakamaru. It was 294 acres, divided into six paddocks with no woolshed or yards. It had a good type of farm house, an implement shed, a deep well and pump and each of the paddocks was watered. The value of the improvements on this blcck was $\$ 18,400$ of which $\$ 4,200$ was paid in cash. Security was taken over a car and other personal assets. At that time the value of the car, horses and dogs and implements was acceptable as part of the deposit.

The farm was settled with 954 ewes and 61 in-calf heifers and 237 ewe lambs and 20 more cows were bought in. Loan money was available for more fencing, water reticulation, yard building and some implements and the total loan at that stage was $\$ 32,000$. The sheep yards were put up immediately and the farm has since been divided into 18 paddocks mainly from 16 to 23 acres with four smaller ones near the house and a 50 acre paddock at the back of the farm.

There were two woolsheds to service the 12 farms so 6 farmers would take it in turns to shear and crutch in one shed and shed hire was paid to the owners. Gradually each farmer has built his own woolshed, and most obtained a further loan to do this. There was one set of cattle yards for all but now each farmer has his own.

While. prices for wool were high these small farms were paying units but, since the drop in price and the cost increases that have taken place recently, there is some doubt about this.

In 1967 the Government indicated that if any sheep farmer thought his farm was too small he coud offer it back and be resettled. Only one farmer in the area did this and in March 1968 his farm was divided up among five neighbours and the writer was allocated 68 acres with the woolshed on it, which was immediately shifted to the home farm. The 68 acres winter 350 
hoggets and $\mathbf{1 5}$ young cattle and it has made a big difference to the total farming situation. Stock wintered this year were 1,100 ewes, 370 ewe hoggets, 50 beef cows, 45 yearlings, 15 two-year-olds and 8 others. This represents 5.5 ewe equivalents per acre. An additional loan of $\$ 11,600$ was needed to finance the extra land.

Table 1 shows the amount. of fertilizer applied and the stock units and wool per acre since taking over.

TABLE 1: FERTILIZER HISTORY

(1961-68, 294 acres; 1968-71, 362 acres)

\begin{tabular}{|c|c|c|c|c|c|}
\hline \multirow{2}{*}{ 1961-2 to } & \multirow{2}{*}{$1964-5$} & \multirow[b]{2}{*}{53} & Type ${ }^{\circ}$ & \multicolumn{2}{|c|}{ Time Applied } \\
\hline & & & Co. Super. & Sep. and & Mar. \\
\hline & $1965-6$ & 53 & Co. Super. & Aug. & \\
\hline & $1966-7$ & 40 & Pot. & Aug. & \\
\hline & $1967-8$ & 44 & $30 \%$ Pot. sup. co. & Aug. & \\
\hline & $1968-9$ & 41 & $50 \%$ Pot. $10 \%$ S. Super. & Oct. & \\
\hline & $1969-70$ & 44 & $30 \%$ Pot. sup. co. & Aug. & \\
\hline & $1970-I$ & 54 & $30 \%$ Pot. sup. co. & Aug. & \\
\hline
\end{tabular}

In the early years, straight superphosphate was applied twice a year. Unwittingly it kept 'sulphur levels adequate, which later proved to be important.

In 1964 potash trials were put down on the property by the Department of Agriculture and they convincingly proved that potash was needed. Plots with $3 \mathrm{cwt} / \mathrm{ac}$ and with $6 \mathrm{cwtjac}$ superphosphate alone showed no visible difference. Superphosphatz with $1 \mathrm{cwt} / \mathrm{ac}$ of potash, and better still $2 \mathrm{cwt} / \mathrm{ac}$ of potash, showed a remarkable response. Consequently $3 \mathrm{cwt}$ of $30 \%$ potassic superphosphate has since been used over the whole farm, applied in late August, or October after lambing. In the spring of $1968,2 \mathrm{cwt} / \mathrm{ac}$ of $50 \%$ potassic superphosphate fortified with sulphur was applied to maintain basic needs of the pasture and also to keep costs down.

Carrying capacity and production during the past ten years are given in Table 2. The drop in wool weights in the last two seasons is due largely to the drought and partly to the lighter clip from the Perendale sheep. In the 1969-70 season there were only 350 Perendale hoggets. shorn, the main flock still being Romneys. All grown sheep are now shorn only once a year, whereas the two-tooths had been shorn twice. All lambs are 
TABLE 2: CARRYING CAPACITY AND PRODUCTION

(1961-68, 294 acres; 1968-71, 362 acres)

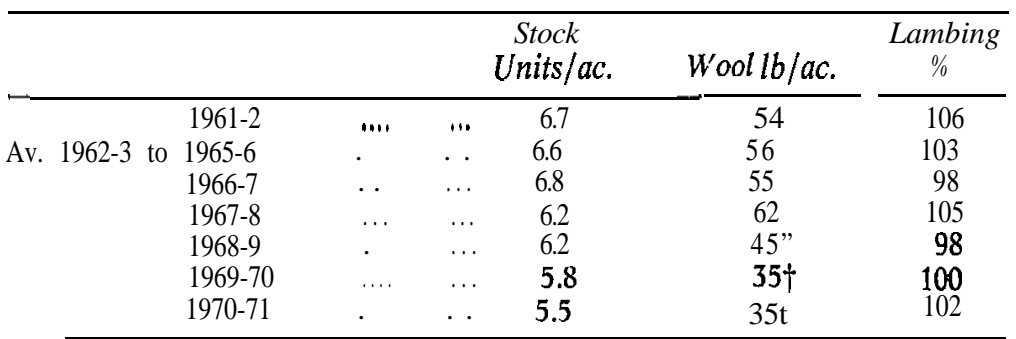

*Cheviot ram used, starting into Perendales.

†Crossbred two-tooths not pre-lup shorn; also droughts experienced.

fattened on the farm. Stocking at the lower level leaves some margin for dry spells and long winters and a higher return from each animal is obtained.

Three years ago it was decided to change from Romneys to Perendales. Difficult births during lambing were the main reason and also more lambs were wanted from the ewe flock. All the information available on Perendale sheep was obtained mainly from the breed society's handbook, and the change-over is now well advanced. Last year $102 \%$ were docked when the district average was down by about $15 \%$. Some of this was due to the Perendale sheep. This spring the lambing was much easier as there were 680 Perendale ewes in the flock.

\section{WINTERING}

The long winter in this area is generally the most difficult period. It usually lasts from early May until the beginning of October when there is little growth. Usually 1,500 bales of hay are harvested, this being the minimum number needed to winter the cattle, and about 16 to 20 acres of swedes and choumoellier are grown to winter the ewes and young cattle.

Grandmaster and Doone Major swedes are sown at $1 \mathrm{lb} / \mathrm{ac}$ and $2 \mathrm{oz} / \mathrm{ac}$ of choumoellier with $4 \mathrm{cwt}$ of super-phosphate plus borax. All the agricultural work is done personally to keep costs down. The ewes start on the crop about the middle of May and it is break fed from a runoff paddock.

Growing swedes and choumoellier is a good method of wintering stock in this area. A good crop of 18 acres will feed 1,100 
ewes for 12 to 14 weeks and much depends on this winter supplementary feed.

Resowing the pasture is another important factor to be considered. The paddock surfaces are usually very rough from the initial sowing, mainly because of the debris left after the first discing. Surface levelling when resowing makes them much better for harvesting and .-reduces the risk of sheep being cast.

\section{PASTURES}

Under land development after burning off the tussock and scrub and giant discing, the Lands and Survey Department sowed the following seed mixture:

$14 \mathrm{lb}$ 'Grasslands Ruanui' perennial ryegrass

$5 \mathrm{lb}$ 'Grasslands Manawa' short-rotation ryegrass

$4 \mathrm{lb}$ 'Grasslands Apanui' cocksfoot

2 lb 'Grasslands Kahu' timothy

2 lb 'Grasslands Hamua' brdad red clover 3 lb 'Grasslands Huia' white clover

At the time of sowing $3 \mathrm{cwt} / \mathrm{ac}$ of cobaltized superphosphate was applied followed by another $3 \mathrm{cwt} / \mathrm{ac} 6$. months later. A further $3 \mathrm{cwt} / \mathrm{ac}$ superphosphate was applied the following spring, making a total of $9 \mathrm{cwt} / \mathrm{ac}$ within the first 12 months. Annual dressings of $3 \mathrm{cwt} / \mathrm{ac}$ of cobaltized superphosphate fol$1 \mathrm{o}$ w e d.

After- the seed strikes, many of the better type grass plants turn yellow because of a shortage of nitrogen, and the cocksfoot and red clover take over. Then, as the red clover disappears, the white clover along with Yorkshire- fog, browntop and some struggling ryegrass, makes up the pasture. It was at this stage, about 6 years after being developed into grass, that these farms were settled on.

The first paddock fenced off was the flattest piece of ground nearer the haybarn. Fifteen acres of the higher country was giant disced and swedes and choumoellier were drilled in and a heavy crop resulted. The paddock was sown into pasture in October using a roller seed-box with the following mixture: 
$12 \mathrm{lb}$ 'Grasslands Ruanui' perennial ryegrass

$2 \mathrm{lb}$ 'Grasslands Paroa' Italian ryegrass

$8 \mathrm{lb}$ 'Grasslands Manawa' short-rotation ryegrass

21/2 lb 'Grasslands Apanui' cocksfoot

$2 \mathrm{lb}$ 'Grasslands Kahu' timothy

$2 \mathrm{lb}$ 'Grasslands Huia' white clover

$11 / 2 \mathrm{lb}$ 'Grasslands Turoa' Montgomery red clover

l lb 'Grasslands Hamua' broad red clover

$31 \mathrm{lb} / \mathrm{ac}$

At sowing, $4 \mathrm{cwt} / \mathrm{ac}$ of serpentine superphosphate was applied. This paddock was cut for hay the second year after sowing and yielded 58 bales per acre and the next year 74 bales per acre. It was used for a hay paddock for seven consecutive years but started to run out so it has not been cut for the past two years. It received an additional $3 \mathrm{cwt} / \mathrm{ac}$ of $30 \%$ potassic superphosphate each year. The paddock is closed in early November and was cut in January when the grasses are in seedhead. This hay, containing a lot of seed, has been fed out systematically over different paddocks and a lot of improvement has taken place in these pastures. Also all the weak spots in a new grass paddock are covered with this type of hay when feeding out.

The seed mixture has been reduced gradually from $30 \mathrm{lb}$ to $23 \mathrm{lb} / \mathrm{ac}$ and good results arc still being obtained. However, in the last two years there has been very dry weather in November and December and a lot of burning off of young plants has resulted.

The following is the seed mixture used in recent years:

$83 / 4 \mathrm{lb}$ 'Grasslands Ariki' ryegrass

$4 \mathrm{lb}$ 'Grasslands Ruanui' perennial ryegrass

$2 \mathrm{lb}$ 'Grasslands Manawa' short-rotation ryegrass

$2 \mathrm{lb}$ 'Grasslands Apanui' cocksfoot

$11 / 4 \mathrm{lb}$ 'Grasslands Kahu' timothy

$3 \mathrm{lb}$ 'Grasslands Huia' white clover

$11 / 3 \mathrm{lb}$ 'Grasslands Hamua' broad red clover

$2 / 3 \mathrm{lb}$ 'Grasslands Turoa' Montgomery red clover

$23 \mathrm{lb} / \mathrm{ac}$

A paddock of the coarse pumice soil type was cut once only for hay and ran out badly. 


\section{MANAGEMENT}

After lambing in September, the ewes and lambs are spread out. The cows are calved in paddocks without sheep and then moved round where needed. Lambs are weaned at the end of December and the cull ewes taken out and sold. The lambs are lightly stocked over selected paddocks and drafted off fat, starting in February. The ewes are rotated around a few paddocks and are used to clean up after the lambs. The hay paddocks are always allowed to recover after taking off hay and they are not heavy stocked at this stage. The tender young clover shoots which will cover the ground are very susceptible to damage at this time and ewes are kept out for at least two weeks.

The only long spell the paddocks get in general is when the ewes are wintering on the swede crop. However, very little growth takes place at this time of the year.

\section{EARTHWORMS}

It appears that very few earthworms existed in this country in its natural state. Possibly there was no food for them amongst the manuka and tussock. The red dung worm Lumbricus rubellus is spreading rapidly over the farm now. About 1963 a big concentration of them was noticed in one of the front paddocks. By putting several strainer posts on their sides in a waterway, it was possible to collect large numbers of them and dig them in around the farm.

In 1967, R. Nielson of Rukuhia Research Station, put down a trial using the more active type of earthworm known as Calliginosa and also provided twelve turfs containing them which were placed around the farm. The worms are still around these various places but have been slow to spread. One of the biggest hold-ups to a good pasture is the layer of undecomposed vegetable matter that forms a mat on top of the soil and earthworm activity may help resolve this problem.

\section{PROBLEMS}

Grass staggers has been severe in some seasons. The year potassic superphosphate dressings were started was generally bad for metabolic trouble and quite a few cows were lost. Undoubtedly, they were too fat and difficult to feed adequately. The next season calcined magnesite and powdered molasses in a liquid form were applied to the hay and no losses occurred; 
other farmers using the lick method of supplying calcined magnesite still lost a few cows that year. The hay method has since continued to be used successfully.

Nodding thistle is a growing problem on the farm and up till now is controlled by hoeing. Grass grub is causing much concern and is a serious problem in the district. So far only a light infestation has been experienced.

Erosion occurs readily in the coarse pumice of the "steeper gullies and necessitates fencing out and tree planting in the trouble spots. When the loose pumice-stony nature of the subsoil becomes exposed, sheep scratch holes in banks for shade. Pumice dust then accumulates in the wool.

The annual rainfall of about 5.5 in. is usually fairly well spread over the year. Other than minor flash floods, no flooding occurs.

Two years ago a drought was experienced and the land burned up very badly. However, prolonged dry spells have been the exception rather than the rule.

In conclusion, we have no regrets in coming to this area. Farming these small farms is interesting and is a continual challenge.

We are making a living and just balancing at the end of each year but unfortunately have had to cut down on farm maintenance. As many of the internal fences are fairly new, it is not really affecting stock management at the moment. It is pleasing to see the trees that were planted 10 years ago reaching $30 \mathrm{ft}$ or more and the shelterbelts becoming effective.

A lot is owed to the Land Settlement Board and the Government departments concerned for settling this very productive area.

\section{DISCUSSION}

Asked by Toxopeus (Ruakura) if he had used soil tests and if they had proved helpful, Ward replied that for the first $\mathbf{5}$ years he had used a blanket coverage of the farm with serpentine superphosphate applied twice a year. Soil tests had been used as a guide after that and the test this year showed a reasonable level of $\mathrm{P}$, but a shortage of potassium. Lancashire (Palmerston North) asked what contribution was made by the main species to his pasture production. Ward said that in the harder grazed areas ryegrass and white clover were making good contribution while timothy and red clover showed up where paddocks had been saved for hay. He preferred hay to silage because of the greater ease of 


\section{FARMING IN PUMICE COUNTRY}

feeding out. Cullen (Invermay) inquired whether the swede and choumoellier cropping system might be dropped as soil fertility increased. Ward considered this a distinct possibility once the whole farm had been worked over and resown in better pastures. He also felt that lucerne would enable him to get by without swedes. Joblin (Ruakura) noted that the stocking rate had been dropped from 6.8 to 5.5 stock units and asked if it was intended to reduce this still further. Ward replied that the average stocking rate of the district was lower than 6.8 stock units. $\mathrm{He}$ had wanted to produce as much as possible but had found that he obtained better lambs at the lower rate and under the conditions prevailing. He hoped he could build up again, perhaps not to 6.8 , but he would definitely not go lower than 5.5 stock units. Gordon (Taupo) commented that the carrying capacity of the whole country had been brought back over the past 7 years and that this had been mainly because of the severe drought conditions which had prevailed. 